\title{
Az elektromos vihar ellátása: a katéteres abláció szerepe
}

\author{
Salló Zoltán, Szegedi Nándor, Merkely Béla, Gellér László
}

\author{
Semmelweis Egyetem, Városmajori Szív- és Érgyógyászati Klinika, Budapest \\ Levelezési cím: Dr. Salló Zoltán, e-mail: sallo.zoltan@net.semmelweis-univ.hu
}

Az elektromos vihar (EV) incidenciája az implantálható kardioverter defibrillátorok (ICD-k) szélesebb indikációs körben történő használatával egyre növekszik. Az EV egyaránt kialakulhat iszkémiás és non-iszkémiás szívbetegségekben is, jelentősen emelve a rövid- és hosszú távú mortalitást. Életveszélyes állapot, amelynek kezelése összetett terápiát igényel, és kihívást jelenthet a tapasztalt kollégák számára is. Az antiaritmiás kezelésre refrakter esetekben a katéteres abláció (CA) jelenthet hatékony megoldást. Habár a rendelkezésre álló adatok nagy része kis betegszámú, nem randomizált vizsgálatokból származik, ezek alapján úgy tűnik, hogy a CA elvégzésével csökkenthető az aritmiák rekurrenciája, és javítható a túlélés. Célkitűzésünk a CA EV kezelésében betöltött szerepének vizsgálata az elérhető nemzetközi irodalmi adatok alapján, valamint az esetleges alternatív terápiás lehetőségek bemutatása.

Kulcsszavak: elektromos vihar, abláció, kamrai tachycardia, kamrafibrilláció, szívtranszplantáció

\section{Treatment of the electrical storm: the role of catheter ablation}

The incidence of electric storm (ES) is increasing with the use of implantable cardioverter defibrillators (ICDs) in a wider range of indications. ES can develop in both ischemic and non-ischemic heart diseases, significantly increasing short and long-term mortality. It is a life-threatening condition, and the treatment can be challenging even for experienced doctors as well. In the antiarrhythmic drug refractory cases, catheter ablation (CA) can be an effective solution. Although much of the available data comes from non-randomized small studies, it appears that CA can reduce the recurrences of arrhythmias and improve survival. The aim of our paper is to investigate the role of CA in the therapy in ES, and to demonstrate possible alternative therapeutic options.

Keywords: electric storm, ablation, ventricular tachycardia, ventricular fibrillation, heart transplantation

\section{Bevezetés}

Az elektromos vihar (EV) életveszélyes klinikai állapot, igazi aritmológiai vészhelyzet, amelyet a szív elektromos instabilitása miatt kialakuló ismétlődő malignus kamrai ritmuszavar (VA) epizódok jellemeznek. Az évek során több, egymástól kissé eltérő EV-t leíró klinikai definíció is született, azonban elmondható, hogy napjainkban a legelfogadottabb definíció szerint a 24 óra alatt bekövetkező, legalább három különálló tartós kamrai tachycardia (VT) vagy kamrafibrilláció (VF) epizódot, valamint a legalább 12 órán át tartó ,,incessant” (folyamatosan jelentkező) VT-t EV-nek nevezzük. Az implantálható kardioverter defibrillátorral (ICD) élő betegeknél EV-ként definiálták a 24 óra alatt több mint 3 adekvát ICD-terápiát (ATP-t vagy sokkot) igénylő, egymástól legalább 5 perc eltéréssel jelentkező ritmuszavar-epizódokat (1).

\section{Epidemiológiai és etiológiai jellemzők}

Az EV előfordulási gyakorisága fokozatosan nő, amely főként a malignus VA-k kialakulása miatt bekövetkező hirtelen szívhalál megelőzésének non-farmakológiás terápiájaként egyre szélesebb indikációs körben hasz- 
nált ICD-implantációval áll kapcsolatban. Az irodalomban rendelkezésünkre álló adatok alapján EV-t szekunder prevenciós indikációval ICD-implantáción átesett betegek esetén $10-40 \%$-ában regisztráltak, ugyanakkor a primer prevenciós indikációval ICD-t kapott betegek esetében csupán 3,5-4\%-ában fordult elő (2). Az EV elöfordulási gyakorisága nagyban függ a betegpopuláció sajátosságaitól, a szívbetegség típusától és az alkalmazott gyógyszeres kezeléstöl is. Habár az EV föként a szívelégtelenségben (iszkémiás és non-iszkémiás eredet) szenvedő pácienseket érinti, számos esetben elöfordul a csökkent balkamra-funkciójú, strukturális szívbetegséggel élő betegekben, valamint strukturális szívbetegség nélkül is (pl. Brugada-szindróma, hosszú-QT-szindróma vagy katekolaminerg polimorf VT) (1). Bizonyos esetekben különböző precipitáló tényezők is szerepet játszhatnak a ritmuszavarok kialakításában, pl. akut iszkémia, gyógyszertoxicitás, elektrolit-háztartási zavarok, tireotoxikózis, krónikus veseelégtelenség, különböző infekciók, valamint korai posztoperatív időszak (3) (1. táblázat). Az EV-t kiváltó akut eltérés csupán a betegek $10-25 \%$-ban felderithető, a betegek nagy részében a korábbi kardiális státuszhoz képest romlás nem észlelhetö, a pontos kiváltó tényező legtöbb esetben ismeretlen (4-6).

Az EV során a ritmuszavarok többnyire (86-97\%) monomorf VT-ként jelentkeznek, azonban elöfordulhatnak csak VF-epizódok (1-21\%) és kevert formák (VT és VF) is (3-14\%). Az EV-t okozó polimorf VT-k incidenciája alacsonyabb, nagyjából 2-8\%-ra tehető (4-10).

Az epidemiológiai vizsgálatok alapján az EV a morbiditást és a mortalitást is fokozza, a betegek felénél két éven belül halálhoz vezet, emiatt adekvát kezelése nélkülözhetetlen (11).

\section{Kezelés}

Az EV kezeléséröl rendelkezésünkre álló adatok leginkább kis betegszámú, retrospektív vizsgálatokból származnak. A klinikai vizsgálatokban az EV előfordulása nagymértékben függött az alkalmazott definíciótól, valamint a vizsgálati populáció jellemzőitől.

Az EV során jelentkező, hosszabb ideig fennálló ritmuszavarok, valamint a többszörös ICD-sokkok a szív pumpafunkciójának romlásához, ezáltal kardiogén sokk kialakulásához, végül többszervi elégtelenséghez vezethetnek. Kezdeti lépésként szükséges a páciens állapotának, társbetegségeinek, a ritmuszavar hemodinamikai tolerálhatóságának felmérése. Mivel az EV életveszélyes állapot, mihamarabbi ellátásra kell törekednünk. Az ismétlődő ICD-sokkok növelik a mortalitást, valamint rontják az életminőséget, emiatt, ha a beteg ICD-vel rendelkezik, annak sürgős lekérdezése, valamint szükségszerü átprogramozása nélkülözhetetlen. A készülék programozásakor a lehetőségekhez mérten a ritmuszavarok ATP-vel való sikeres terminálására kell törekedni $(12,13)$. Különösen sürgető a helyzet abban az esetben, ha a beteg magas rizikócsoportba sorolható (pl. a szisztolés vérnyomás sinusritmusban, vazopresszor-támogatás mellett tartósan $<80-90 \mathrm{Hgmm}$, vagy a beteg súlyos társbetegséggel - bal kamrai ejekciós frakció (BKEF) $\leq 30 \%$, közepes vagy súlyos veseelégtelenség, súlyos COPD - rendelkezik). Az intenzív ellátást biztosító osztályon való elhelyezés mellett fontos a gyógyszeres terápia optimalizálása, valamint az akut iszkémia és a lehetséges egyéb reverzibilis okok kizárása. Amennyiben szükséges, gépi lélegeztetés, esetleges mechanikus keringéstámogatás (intra-aortikus ballon pumpa [IABP], bal kamrai keringéstámoga-

1. TÁBLÁZAT. Az elektromos vihar definiálása, előfordulása és prognózisa különböző szerzők által (3)

\begin{tabular}{|c|c|c|c|}
\hline Szerzö & Definíció & Incidencia & Prognózis \\
\hline Kowey & $\geq 2$ hemodinamikailag releváns VT $24 \mathrm{~h}$ alatt & Összes páciens & $\downarrow$ \\
\hline Credner & $\geq 3$ VT $24 \mathrm{~h}$ alatt & $14 / 136(10 \%)$ & $\varnothing$ \\
\hline Nademanee & $\geq 20$ VT $24 \mathrm{~h}$ vagy $\geq 41 \mathrm{~h}$ alatt & Összes páciens & $\begin{array}{l}\downarrow \text { ( } 1 \text { éves halálozási arány } 95 \% \text { AAD } \\
\text { mellett és } 33 \% \text {-blokkoló mellett) }\end{array}$ \\
\hline Exner & $\geq 3$ VT $24 \mathrm{~h}$ alatt & $90 / 457(20 \%)$ & $\downarrow(\operatorname{RR} 2,4)$ \\
\hline Greene & $\geq 3$ VT $24 \mathrm{~h}$ alatt & $40 / 227(18 \%)$ & $\varnothing$ \\
\hline Bansch & $\geq 3$ VT $24 \mathrm{~h}$ alatt & $30 / 106(28 \%)$ & $\downarrow$ \\
\hline Verma & $\geq 2$ sokkot igénylő VT $24 \mathrm{~h}$ alatt & $208 / 2028(10 \%)$ & $\downarrow$ \\
\hline Wood & $\geq 3$ VT $24 \mathrm{~h}$ alatt & $50 / 521(24 \%)$ & Nem vizsgálták \\
\hline Stuber & $\geq 3$ VT 2 hét alatt & $51 / 214(24 \%)$ & $\downarrow$ (5 éves halálozási arány $33 \%$ vs. $13 \%$ ) \\
\hline Hohnloser & \3 különálló VT 24 h alatt & $148 / 633(23 \%)$ & $\varnothing$ \\
\hline Brigadeau & 22 különálló VT 24 h alatt & $123 / 307(40 \%)$ & $\varnothing$ \\
\hline Gatzoulis & $\geq 3$ VT $24 \mathrm{~h}$ alatt & $32 / 169(19 \%)$ & $\begin{array}{l}\downarrow \text { (halálozási arány } 53 \% \text { vs. } 14 \% 33 \pm 26 \\
\text { hónap alatt) }\end{array}$ \\
\hline Sesselberg & $\geq 3$ VT 24 h alatt & $169 / 719(24 \%)$ & $\downarrow$ \\
\hline Guerra & $\geq 3$ VT 24 h alatt & $857 / 5912(14 \%)$ & $\downarrow(\mathrm{RR} 2,15)$ \\
\hline
\end{tabular}

$\mathrm{AAD}=$ antiaritmiás gyógyszer; $\mathrm{RR}$ = relatív rizikó; $\downarrow$ = csökkent prognózis; $\varnothing=$ nincs hatással a prognózisra 


\section{TÁBLÁZAT. Az elektromos vihar kezelésének lehetőségei (19)}

Intenzív osztályos ellátás

Eszközprogramozás

Reverzibilis eltérések korrigációja (pl. iszkémia, ionháztartási zavar, gyógyszerhatás)

Béta-blokkoló

Egyéb antiaritmiás terápia

Mechanikus keringéstámogatás

Neuraxiális moduláció (pl. torakális epiduralis anesztézia, kardiális szimpatikus denerváció, ggl. stellatum blokád, renális denerváció)

Katéteres abláció (bármikor, amennyiben kivitelezhetö)

Szívtranszplantáció

Alternatív lehetőségek (pl. transzkoronáriás etanolos abláció, sebészi abláció, aneurysmectomia, sztereotaxiás besugárzás)

tó eszköz [LVAD], extrakorporális membrán oxigenátor [ECMO]) alkalmazandó.

\section{A katéteres abláció szerepe}

Amennyiben EV esetén a ritmuszavarok a megkezdett antiaritmiás gyógyszeres (AAD) terápia, valamint a reverzibilis okok rendeződését követően is ismétlődnek, valamint ha az AAD-terápia hatásos, azonban a mellékhatásai nem tolerálhatók, a betegnél a rádiófrekvenciás katéteres abláció (CA) javasolt (14). Az Európai Kardiológus Társaság legújabb ajánlása alapján urgens $C A$ javasolt hegesedéssel járó szívbetegségben incessant $V T$ vagy $E V$ esetén (I/B-ajánlás) (14). Napjainkban a CA az EV-ben jelentkező VA-k hatékony és definitív terápiája $(11,15-18)$, habár a non-iszkémiás szívbetegek esetén történő VT CA-nak hosszú távú sikeressége általában elmarad az iszkémiás esetek sikerességétől (2. táblázat).

$A z$ aritmiaszubsztráttól függően - amely az alapbetegségtöl függ - endokardiális és epikardiális abláció is lehetséges. Iszkémiás szívbetegségben az aritmiaszubsztrát - maga az iszkémiás heg - gyakrabban helyezkedik el endokardiálisan. Az elhalt és élő sejtek közti területek (,,határzónák”) típusos kiindulási helyei a reentry mechanizmusú VT-knek. Ezzel szemben a non-iszkémiás szívbetegség talaján kialakuló VA-k esetében az aritmiaszubsztrát gyakrabban érinti az epikardiális régiót is $(2,20)$. Ezen aritmiakörök, aritmiaszubsztrátok eliminálásához elengedhetetlenül szükséges az érintett terület precíz elektroanatómiai feltérképezése, amely manapság modern háromdimenziós térképező rendszerekkel történik. A VT térképezése történhet sinusritmusban, vagy amennyiben nem okoz hemodinamikai instabilitást, ritmuszavar alatt is, ún. aktivációs térképezéssel. Amennyiben rendelkezésre áll, perkután kamrai keringéstámogató eszköz is használható, mivel ezzel a VT-ritmuszavar alatt is biztonságosabban térképezhető (21). Az abláció előtti speciális algoritmusok segítségével elvégzett szív MR-vizs- gálat segítséget nyújthat az aritmiaszubsztrát még pontosabb lokalizációjában. A sok esetben a bal kamrában található heges területek retrográd transzaortikus behatolásból vagy transseptalis úton érhetök el, míg az epikardiális abláció subxyphoidealis behatolást igényel. A ritmuszavarok ablációja során több stratégia is alkalmazható: végezhető ún. „dechanelling” (az aritmiakörök különböző régióinak - entrance, isthmus és exit régió pontos azonosítása után ezek ablációja), LAVA (lokális abnormális kamrai aktiváció) és késői potenciálelimináció, vagy endo- és/vagy epikardiális heghomogenizáció is. Az akut iszkémiás szívbetegségben az EV-t időnként kamrai extraszisztóliák indukálhatják, ebből kifolyólag az akut miokardiális infarktus után jelentkező EV esetében alternatív lehetőséget jelenthet magának a kiváltó extraszisztóliának az ablációja (22). Ugyanakkor úgy tünik, hogy krónikus iszkémiás szívbetegség vagy egyéb cardiomyopathia esetén az EV kiváltásában szerepet játszanak ettől eltérő mechanizmusok is (23). Időnként a VT-t sinus tachycardia, supraventricularis tachycardia vagy pitvarfibrillációs epizód előzi meg, amelyek szerepet játszhatnak az ingervezetés lassulásában, a reentry mechanizmus és ezáltal a VT kialakulásában. A Torsade de pointes (TdP) típusú aritmiát általában egy VES által kiváltott pausa előzi meg (24).

Habár a VA-k CA-ja hosszú múltra tekint vissza, az adatok többsége esettanulmányokból vagy kis betegszámú retrospektív vizsgálatokból származik. A rádiófrekvenciás CA nemcsak az EV rövidtávú kezelésében sikeres (a betegek $80-90 \%$-ban uralhatóvá vált a ritmuszavar), hanem hosszú távon is javítja az aritmiamentes túlélést (3. táblázat) (1).

Carbucicchio és munkatársai közleménye alapján EV esetén a CA segítségével a sinusritmus hét napos kórházi obszerváció alatt stabilan tartható volt. Magának a klinikai ritmuszavarnak az eliminálása jelentősen csökkentette a kardiális eredetủ halálozást. Amennyiben az abláció után VT egyáltalán nem volt indukálható (az abláció végén programozott kamrai extrastimulációval ritmuszavar nem volt kiváltható) hosszú távon a VT-rekurrencia is csökkent (17). Az EV esetében végzett $C A$ mind az alacsony, mind a magas kockázatú páciensek esetében csökkentette a VT-rekurrenciát, valamint javította a túlélést (25). A VANISH-vizsgálatban a CA-val kezelt betegeknél az EV-rekurrenciáját illetően 34\%-os relatív kockázatcsökkenést tapasztaltak az AAD-terápiával kezelt csoporttal szemben (26). Egy 471 EV miatt abláción átesett betegeket magába foglaló metaanalízis során a klinikai ritmuszavar az ablációval betegek $91 \%$ ban volt visszaszorítható, míg az összes indukálható VA akut eliminációja az esetek $72 \%$-ában volt sikeres. Szövődmények 2\%-ban, a beavatkozással összefüggő haláleset pedig kevesebb, mint 1\%-ban fordult elő. A hosszú távú utánkövetés alatt (átlagos utánkövetési idő 61 hét) a betegek 94\%-a volt EV-mentes, $72 \%$ ban VA-t egyáltalán nem regisztráltak. A hosszú távú utánkövetés alatt a teljes mortalitás $17 \%$ volt, a legtöbb 


\begin{tabular}{|c|c|c|c|c|c|c|c|c|}
\hline Ref. & $\begin{array}{l}\text { Betegek } \\
\text { száma }\end{array}$ & BKEF & $\begin{array}{l}\text { Epikardiá- } \\
\text { lis beavat- } \\
\text { kozás }\end{array}$ & $\begin{array}{l}\text { Akut } \\
\text { sike- } \\
\text { resség }\end{array}$ & $\begin{array}{l}\text { VT-rekur- } \\
\text { rencia }\end{array}$ & $\begin{array}{l}\text { EV-rekur- } \\
\text { rencia }\end{array}$ & $\begin{array}{l}\text { Halál- } \\
\text { eset }\end{array}$ & $\begin{array}{l}\text { Utánkö- } \\
\text { vetési idő } \\
\text { (hónap) }\end{array}$ \\
\hline Sra és mtsai & 19 & $27 \pm 8$ & $0 \%$ & $87 \%$ & $37 \%$ & - & $0 \%$ & $7 \pm 2$ \\
\hline Silva és mtsai & 14 & $31 \pm 13$ & $20 \%$ & $80 \%$ & $13 \%$ & - & $27 \%$ & $12 \pm 17$ \\
\hline $\begin{array}{l}\text { Carbucicchio és } \\
\text { mtsai }\end{array}$ & 95 & $36 \pm 11$ & $11 \%$ & $89 \%$ & $34 \%$ & $8 \%$ & $16 \%$ & Medián 22 \\
\hline Arya és mtsai & 13 & $33 \pm 9$ & $31 \%$ & $100 \%$ & $38 \%$ & - & $31 \%$ & Medián 23 \\
\hline Pluta és mtsai & 21 & - & $0 \%$ & $81 \%$ & $19 \%$ & $0 \%$ & $0 \%$ & 3 \\
\hline Deneke és mtsai & 31 & $28 \pm 15$ & $9 \%$ & $94 \%$ & $25 \%$ & $12 \%$ & $9 \%$ & Medián 15 \\
\hline $\begin{array}{l}\text { Kozeluhova és } \\
\text { mtsai }\end{array}$ & 50 & $29 \pm 11$ & $0 \%$ & $85 \%$ & $52 \%$ & $26 \%$ & $29 \%$ & $18 \pm 16$ \\
\hline Koźluk és mtsai & 24 & $27 \pm 7$ & $7 \%$ & - & $34 \%$ & $12 \%$ & $13 \%$ & $28 \pm 16$ \\
\hline Di Biase és mtsai & 92 & $27 \pm 5$ & $47 \%$ & $100 \%$ & $34 \%$ & $0 \%$ & $2 \%$ & $25 \pm 10$ \\
\hline $\begin{array}{l}\text { Izquierdo és } \\
\text { mtsai }\end{array}$ & 23 & $34 \pm 10$ & $0 \%$ & $56 \%$ & - & $35 \%$ & $30 \%$ & Medián 18 \\
\hline Jin és mtsai & 40 & $21 \pm 7$ & $0 \%$ & $80 \%$ & $53 \%$ & - & $25 \%$ & $17 \pm 17$ \\
\hline Kumar és mtsai & 287 & $\begin{array}{l}27 \pm 10(\mathrm{ICM}) \\
\text { és } 33 \pm 16 \\
(\mathrm{NICM})\end{array}$ & $\begin{array}{l}3,8 \%(\mathrm{ICM}) \\
\text { és } 24 \% \\
\text { (NICM) }\end{array}$ & $\begin{array}{l}60 \%(\mathrm{ICM}) \\
\text { és } 50 \% \\
\text { (NICM) }\end{array}$ & $\begin{array}{l}49 \%(\mathrm{ICM}) \\
\text { és } 64 \% \\
\text { (NICM) }\end{array}$ & $\begin{array}{l}17 \%(\text { ICM) } \\
\text { és } 27 \% \\
\text { (NICM) }\end{array}$ & $\begin{array}{l}25 \%(\mathrm{ICM}) \\
\text { és } 28 \% \\
\text { (NICM) }\end{array}$ & Medián 42 \\
\hline Muser és mtsai & 267 & $29 \pm 13$ & $22 \%$ & $73 \%$ & $33 \%$ & $5 \%$ & $29 \%$ & Medián 45 \\
\hline
\end{tabular}

(ICM = iszkémiás cardiomyopathia, NICM = non-iszkémiás cardiomyopathia)

haláleset hátterében szívelégtelenség progresszió állt (62\%) (27). Hasonló eredményekről számoltak be egy másik 267 gyógyszerrefrakter EV miatt CA-n átesett beteget magába foglaló vizsgálatban, amely során a rekurrenciát észlelő betegek esetében a VT előfordulási gyakorisága szignifikánsan csökkent (28). Egy másik, 1940 VT-abláción átesett beteget vizsgáló tanulmányban 677 páciensnél jelentkezett EV. Ezen páciensek esetében az elektrofiziológiai vizsgálat során több VT is indukálható volt, és az abláció is hosszabb időt vett igénybe. EV esetén a hospitalizáció közbeni halálozás is $(6,2$ vs. $1,4 \%)$, valamint a 12 hónapos utánkövetés során az ICD által detektált VT-rekurrencia is magasabb volt az EfV-ben nem szenvedő páciensekhez képest (32 vs. 23\%) (29).

Habár a CA-mortalitás csökkentő hatása EV-ban vagy incessant VT-ben szenvedő betegek esetén nem teljesen tisztázott, a CA az önálló gyógyszeres terápiával szemben szignifikánsan csökkentette a ritmuszavarok előfordulási gyakoriságát, javítva ezáltal a túlélést is (26, 28, 30-32). Egy korábbi vizsgálatban 52 EV-vel jelentkező páciens adatait hasonlították össze. 29 beteg esetében elsődleges kezelésként csak farmakológiai terápiát, a többi beteg esetében pedig csak CA-t alkalmaztak. Az EV visszatérési valószínűsége szignifikánsan csökkent a CA-n átesett betegek esetében, habár a túlélésben nem mutatkozott jelentős különbség az utánkövetési idő alatt (a medián utánkövetési idő 28 hónap volt) (33).

Napjainkban az invazív elektrofiziológia rohamos fejlődésével már rendkívül modern eszközök állnak rendel- kezésünkre. Mindazonáltal az EV miatt abláción átesett betegek esetében a hosszú távú prognózis még mindig rosszabb (a VT-rekurrencia és a mortalitás is magasabb), mint a nem EV (egyéb malignus kamrai ritmuszavar epizód) miatt CA-n átesett betegek esetében.

\section{Alternatív lehetőségek}

Azokban az esetekben, amelyekben a CA nem jár sikerrel vagy valamilyen tényező miatt nehézségekbe ütközik (pl. mechanikus mübillentyű esetén), alternatív, definitív vagy áthidaló megoldást jelentő lehetőségek is rendelkezésünkre állnak. Amennyiben a CA nem járt sikerrel, megfelelő tapasztalattal rendelkező operatőr esetén hatékony megoldást jelenthet a sebészi cryoabláció (34), továbbá bal kamrai aneurizma területéről kiinduló ritmuszavar esetén a sebészi aneurysmectomia. További alternatíva még a transzkoronáriás etanolos abláció, amely során szelektív koronarográfia segítségével azonosítják a VT-t okozó szívizomterületet ellátó koszorúérágat, majd etanol infundálásával roncsolják azt (35). Megfontolható még a renális denerváció (36), a kardiális szimpatikus denerváció (37), a torakális epidurális anesztézia, a ganglion stellátumnak a blokádja (38), valamint a jelenleg még gyerekcipőben járó sztereotaxiás besugárzás (39).

A nemzetközi irodalomban kevés adat áll rendelkezésre az EV miatt végzett szívtranszplantációval kapcsolatban. Napjainkban a szívtranszplantáció egyre több helyen elérhető. Az eddigi adatok alapján, amennyiben az EV továbbra is visszatér gyógyszeres terápia és a CA ellenére, és amennyiben nem áll fenn kontraindiká- 
ció, a szívtranszplantáció mindenképpen megfontolandó, hiszen definitív megoldást jelenthet a beteg számára $(19,40)$.

\section{Megbeszélés}

\begin{abstract}
Habár a nemzetközi irodalomban kissé eltérő definíciók használatosak az EV jellemzésére, mindenképpen egy életet veszélyeztető, azonnali ellátást igénylő kórképről van szó. Az ICD-implantációk számának szaporodásával, valamint a szívelégtelenség-terápia fejlődésével az EV incidenciája is növekedett. Az EV kezelése öszszetett feladat, magába foglalja az ICD optimális programozását, a lehetséges kiváltó okok megszüntetését, valamint a gyógyszeres és eszközös terápiás megoldásokat is. A gyógyszerrefrakter esetekben a rádiófrekvenciás CA választandó, amely csökkenti a VA-k elöfordulási gyakoriságát rövid- és hosszú távon egyaránt, javítva ezzel a morbiditást és a mortalitást. Amennyiben a CA sikertelen, alternatív terápiás lehetőségek is rendelkezésre állnak, azonban, ha a páciensnek jó túlélési esélye van, nem szabad megfeledkeznünk a sürgető szívtranszplantáció mint definitív terápia lehetőségéröl sem.
\end{abstract}

Irodalom

1. Muser D, Santangeli P, Liang JJ. Management of ventricular tachycardia storm in patients with structural heart disease. World $\mathrm{J}$ Cardiol 2017; 9(6): 521-30. doi: 10.4330/wjc.v9.i6.521

2. Conti S, Pala S, Biagioli V, et al. Electrical storm: A clinical and electrophysiological overview. World J Cardiol 2015; 7(9): 555-61. doi: 10.4330/wjc.v7.i9.555

3. Sagone A. Electrical Storm: Incidence, Prognosis and Therapy. J Atr Fibrillation 2015; 8(4): 1150. doi: 10.4022/jafib.1150

4. Hohnloser SH, Al-Khalidi HR, Pratt CM, et al. Electrical storm in patients with an implantable defibrillator: incidence, features, and preventive therapy: insights from a randomized trial. Eur Heart $\mathrm{J}$ 2006; 27(24): 3027-32. doi: 10.1093/eurheartj/ehl276

5. Bansch D, Bocker D, Brunn J, et al. Clusters of ventricular tachycardia's signify impaired survival in patients with idiopathic dilated cardiomyopathy and implantable cardioverter defibrillators. J Am Coll Cardiol 2000; 36(2): 566-73. doi: 10.1016/S0735-1097(00)00726-9 6. Credner SC, Klingenheben T, Mauss $\mathrm{O}$, et al. Electrical storm in patients with transvenous implantable cardioverter-defibrillators: incidence, management and prognostic implications. J Am Coll Cardiol 1998; 32(7): 1909-15. doi: 10.1016/S0735-1097(98)00495-1

7. Greene M, Newman D, Geist M, et al. Is electrical storm in ICD patients the sign of a dying heart? Outcome of patients with clusters of ventricular tachyarrhythmias. Europace 2000; 2(3): 263-9. doi: 10.1053/eupc.2000.0104

8. Exner DV, Pinski SLO, Wyse DG, et al. Electrical storm presages nonsudden death: the antiarrhythmics versus implantable defibrillators (AVID) trial. Circulation 2001; 103(16): 2066-71. doi: 10.1161/01. CIR.103.16.2066

9. Sesselberg HW, Moss AJ, McNitt S, et al. Ventricular arrhythmia storms in postinfarction patients with implantable defibrillators for primary prevention indications: a MADIT-II substudy. Heart Rhythm 2007; 4(11): 1395-402. doi: 10.1016/j.hrthm.2007.07.013

10. Brigadeau F, Kouakam C, Klug D, et al. Clinical predictors and prognostic significance of electrical storm in patients with implantable cardioverter defibrillators. Eur Heart J 2006; 27(6): 700-7. doi: 10.1093/eurheartj/ehi726

11. Deneke T, Shin DI, Lawo T, et al. Catheter ablation of electrical storm in a collaborative hospital network. Am J Cardiol 2011; 108(2): 233-9. doi: 10.1016/j.amjcard.2011.03.030

12. Moss AJ, Schuger C, Beck CA, et al. Reduction in inappropriate therapy and mortality through ICD programming. N Engl J Med 2012; 367(24): 2275-83. doi: 10.1056/NEJMoa1211107

13. Poole JE, Johnson GW, Hellkamp AS, et al. Prognostic importance of defibrillator shocks in patients with heart failure. $\mathrm{N}$ Engl $\mathrm{J}$ Med 2008; 359(10): 1009-17. doi: 10.1056/NEJMoa071098

14. Priori SG, Blomstrom-Lundqvist C. 2015 European Society of Cardiology Guidelines for the management of patients with ventricular arrhythmias and the prevention of sudden cardiac death summarized by co-chairs. Eur Heart J 2015; 36(41): 2757-9. doi: 10.1093/ eurheartj/ehv445

15. Al-Khatib SM, Stevenson WG, Ackerman MJ, et al. 2017 AHA/ ACC/HRS Guideline for Management of Patients With Ventricular Arrhythmias and the Prevention of Sudden Cardiac Death: A Report of the American College of Cardiology/American Heart Association Task Force on Clinical Practice Guidelines and the Heart Rhythm Society. J Am Coll Cardiol 2017. doi: 10.1161/CIR.0000000000000549 16. Gorenek B, Blomstrom Lundqvist C, et al. Cardiac arrhythmias in acute coronary syndromes: position paper from the joint EHRA, ACCA, and EAPCI task force. Eurolntervention 2015; 10(9): 1095108. doi: 10.4244/EIJY14M08_19

17. Carbucicchio C, Santamaria M, Trevisi N, et al. Catheter ablation for the treatment of electrical storm in patients with implantable cardioverter-defibrillators: short- and long-term outcomes in a prospective single-center study. Circulation 2008; 117(4): 462-9. doi: 10.1161/CIRCULATIONAHA.106.686534

18. Tan VH, Yap J, Hsu LF, Liew R. Catheter ablation of ventricular fibrillation triggers and electrical storm. Europace 2012; 14(12): 1687-95. doi: 10.1093/europace/eus050

19. Pedersen CT, Kay GN, Kalman J, et al. EHRA/HRS/APHRS expert consensus on ventricular arrhythmias. Heart Rhythm 2014; 11(10): e166-96. doi: 10.1093/europace/euu194

20. Yamada T, Kay GN. Optimal ablation strategies for different types of ventricular tachycardias. Nat Rev Cardiol 2012; 9(9): 512-25. doi: 10.1038/nrcardio.2012.74

21. Bunch TJ, Mahapatra S, Madhu Reddy Y, Lakkireddy D. The role of percutaneous left ventricular assist devices during ventricular tachycardia ablation. Europace 2012;14(Suppl 2): ii26-ii32. doi: 10.1093/europace/eus210

22. Bansch D, Oyang F, Antz M, et al. Successful catheter ablation of electrical storm after myocardial infarction. Circulation 2003; 108(24): 3011-6. doi: 10.1161/01.CIR.0000103701.30662.5C

23. Chan KH, Sy RW. Catheter Ablation of Recurrent Ventricular Fibrillation: A Literature Review and Case Examples. Heart Lung Circ 2016; 25(8): 784-90. doi: 10.1016/j.hlc.2016.02.008

24. Ulus T, Kudaiberdieva G, Gorenek B. The onset mechanisms of ventricular tachycardia. Int J Cardiol 2013; 167(3): 619-23. doi: 10.1016/j.ijcard.2012.09.034

25. Della Bella P, Baratto F, Tsiachris D, et al. Management of ventricular tachycardia in the setting of a dedicated unit for the treatment of complex ventricular arrhythmias: long-term outcome after ablation. Circulation 2013; 127(13): 1359-68. doi: 10.1161/CIRCULATIONAHA.112.000872

26. Sapp JL, Wells GA, Parkash R, et al. Ventricular Tachycardia Ablation versus Escalation of Antiarrhythmic Drugs. N Engl J Med 2016; 375(2): 111-21. doi: 10.1056/NEJMoa1513614

27. Nayyar S, Ganesan AN, Brooks AG, et al. Venturing into ventricular arrhythmia storm: a systematic review and meta-analysis. Eur Heart J 2013; 34(8): 560-71. doi: 10.1093/eurheartj/ehs453 
28. Muser D, Liang JJ, Pathak RK, et al. Long-Term Outcomes of Catheter Ablation of Electrical Storm in Nonischemic Dilated Cardiomyopathy Compared With Ischemic Cardiomyopathy. JACC Clin Electrophysiol 2017; 3(7): 767-78. doi: 10.1016/j.jacep.2017.01.020 29. Vergara $P$, Tung $R$, Vaseghi $M$, et al. Successful ventricular tachycardia ablation in patients with electrical storm reduces recurrences and improves survival. Heart Rhythm 2018; 15(1): 48-55. doi: 10.1016/j.hrthm.2017.08.022

30. Liang JJ, Muser D, Santangeli P. Ventricular Tachycardia Ablation Clinical Trials. Card Electrophysiol Clin 2017; 9(1): 153-65

31. Santangeli P, Muser D, Maeda S, et al. Comparative effectiveness of antiarrhythmic drugs and catheter ablation for the prevention of recurrent ventricular tachycardia in patients with implantable cardioverter-defibrillators: A systematic review and meta-analysis of randomized controlled trials. Heart Rhythm 2016; 13(7): 1552-9. doi: 10.1016/j.hrthm.2016.03.004

32. Tung R, Vaseghi M, Frankel DS, et al. Freedom from recurrent ventricular tachycardia after catheter ablation is associated with improved survival in patients with structural heart disease: An International VT Ablation Center Collaborative Group study. Heart Rhythm 2015; 12(9): 1997-2007. doi: 10.1016/j.hrthm.2015.05.036

33. Izquierdo M, Ruiz-Granell R, Ferrero A, C, et al. Ablation or conservative management of electrical storm due to monomorphic ventricular tachycardia: differences in outcome. Europace 2012; 14(12): 1734-9. doi: 10.1093/europace/eus186
34. Liang JJ, Betensky BP, Muser D, et al. Long-term outcome of surgical cryoablation for refractory ventricular tachycardia in patients with non-ischemic cardiomyopathy. Europace 2018; 20(3): e30-e41. doi: 10.1093/europace/eux029

35. Kumar S, Barbhaiya CR, Sobieszczyk P, K, et al. Role of alternative interventional procedures when endo- and epicardial catheter ablation attempts for ventricular arrhythmias fail. Circ Arrhythm Electrophysiol 2015; 8(3): 606-15. DOI: 10.1161/CIRCEP.114.002522 36. Remo BF, Preminger M, Bradfield J, et al. Safety and efficacy of renal denervation as a novel treatment of ventricular tachycardia storm in patients with cardiomyopathy. Heart Rhythm 2014; 11(4): 541-6. doi: 10.1016/j.hrthm.2013.12.038

37. Vaseghi M, Barwad P, Malavassi Corrales FJ, et al. Cardiac Sympathetic Denervation for Refractory Ventricular Arrhythmias. J Am Coll Cardiol 2017; 69(25): 3070-80. doi: 10.1016/j.jacc.2017.04.035 38. Meng L, Tseng $\mathrm{CH}$, Shivkumar K, Ajijola O. Efficacy of Stellate Ganglion Blockade in Managing Electrical Storm: A Systematic Review. JACC Clin Electrophysiol 2017; 3(9): 942-9. doi: 10.1016/j. jacep.2017.06.006

39. Cuculich PS, Robinson CG. Noninvasive Ablation of Ventricular Tachycardia. N Engl J Med 2018; 378(17): 1651-2. doi: 10.1056/ NEJMc1802625

40. Mancini D, Lietz K. Selection of cardiac transplantation candidates in 2010. Circulation 2010; 122(2): 173-8. doi: 10.1161/CIRCULATIONAHA.109.858076 